\title{
Local Civil Service:
}

From Internal Mobility to Spatial Mobility?

Fonction publique territoriale : de la mobilité interne à la mobilité spatiale?

\section{Émilie Biland}

\section{(2) OpenEdition}

\section{Journals}

Electronic version

URL: http://journals.openedition.org/travailemploi/6290

DOI: 10.4000/travailemploi.6290

ISSN: 1775-416X

Publisher

DARES - Ministère du Travail

\section{Printed version}

Date of publication: 15 December 2013

Number of pages: 19-32

ISSN: 0224-4365

\section{Electronic reference}

Émilie Biland, «Local Civil Service: », Travail et Emploi [Online], Hors-série | 2013, Online since 01

January 2014, connection on 20 April 2019. URL : http://journals.openedition.org/travailemploi/6290 ; DOI : 10.4000/travailemploi.6290

\section{(C) La documentation française}




\title{
Local Civil Service: From Internal Mobility to Spatial Mobility? ${ }^{*}$
}

\author{
Émilie Biland $\left.{ }^{* *}\right)$
}

\begin{abstract}
In contrast to their peers working for the State, the trajectories of local government employees have long been marked by stability instead of spatial mobility. This article re-examines this local hiring and career model and analyses its contemporary critiques, through a quantitative and qualitative analysis of the personnel files of a small city. The rising importance of geographical mobility is concomitant with the increasing rarity of social mobility over the course of one's working life, and yet the majority of this city's public employees remain locally rooted. To understand the limited progress of the effort to make professional careers mobile, the article identifies the unequal costs and benefits of mobility according to generational, social, and gendered factors.
\end{abstract}

"If you are not appointed in the three months after having passed the concours, ${ }^{(1)}$ France opens her arms to you! The concours are valid nationally, and no one can impose a transfer on you, as in the State civil service. And Savoie is beautiful!"

Spoken enthusiastically at a 2007 public job fair (2) by a senior official in the General Council of the alpine department of Savoie, ${ }^{(3)}$ this speech is typical of contemporary urging to professional relocation in the French local civil service (LCS, fonction publique territoriale). According to the speaker, this spatial mobility allows job seekers to experience deviations in their expected career paths as positive, because the new path would be chosen instead of imposed. Distancing itself from the State civil service (SCS) - using an old posture that experienced a revival with the advent of decentralization in the 1980s- this approach also serves to promote his department, a reminder that local authorities took the "territorial marketing" path, as much for recruiting their own personnel as for attracting businesses to the area (LE BART, 2011).

$(*)$ Article published in French in Travail et emploi, $\mathrm{n}^{\circ}$ 127, juillet-septembre 2011.

(**) Université Laval, Québec, Canada; emilie.biland@pol. ulaval.ca

(1) A concours is an organized competition for a public job, which usually includes a written exam as a first step, followed by interviews.

(2) Agora, "Intégrer la fonction publique : comment préparer un concours?", Fourth Salon de l'emploi public, Paris, Palais des congrès, March 29, 2007.

(3) A commune is the smallest French administrative unit regardless of its size, equivalent to a city, town, or village, headed by a mayor and council. The next scale up is that of the department (département). France has 101 departments, each led by a political institution called the General Council (Conseil Général). The next level up is the region (région), then the State (l'Etat).
Such a position begs for the study of different forms of mobility in the local public service. It should be said from the outset that this job fair speech goes against the image -largely empirically founded, as we shall see- of a civil service that historically was little mobile. The existence of close connections between local public employees and the territory where they work and live is an old story regularly evoked in describing this segment of public employment. In Tozay, the municipality (commune) discussed in this article, three-quarters of municipal jobs are held by residents. More than half of city employees were born in the city, and three-quarters of them were born in the same department.

In fact, geographical mobility -as statutory obligation, corporate norm, and practical constraint- has never been as present in the LCS as it was in the SCS, which is known for producing "uprooted" people (Blum, DE LA Gorce, ThÉLOt, 1985, p. 424). Historians of the Third Republic (1871-1940) have demonstrated that in local government, local backgrounds in fact used to function as a priority criterion for hiring. Recruiting newcomers from rural regions was not impossible, of course, especially in the Paris area, but it stabilized their residential trajectories and contributed to their integration into suburban society (Bellanger, 2008). Having persisted through the 1970s and even the 1980s, although to various degrees depending on the employer and hierarchical position, this model has since begun to erode. At a time when the new spirit of capitalism values flexibility over rigidity and adaptability over local roots (Boltanski, ChiAPELlo, 1999, p. 179), is it local public employment's turn to be affected by the "generalized making mobile" of professional careers (CASTEL, 2003, p. 43) whose post-Fordistera development has been shown by several surveys (Chapoulie, 2000)? 
To explore this question, this article examines discourse and legal texts related to the LCS, which has become favorable to geographical mobility, and effective forms of local public employee mobility. We will test the hypothesis that internal professional mobility is on the decline in local governments to the benefit of geographical mobility, itself a tool for professional ascension. So, have the conditions for social mobility through work ${ }^{(4)}$ been transformed since the 1970s? In the four decades following World War II, the civil service was a "milieu particularly favorable to social ascension" (GoLLAC, 2005, pp. 50-51), especially for women and for employees with workingclass backgrounds. In local governments, where employees had lower educational levels than those working for the State, trajectories of intergenerational social ascension have been explained less by academic success than by methods of internal guidance following a "localist-municipalist" logic (Burlen, Thoenig, 1998). Today this association between local hiring and internal mobility is challenged by heightened academic selectivity during hiring and by the development of job transfers between local governments. Horizontal mobility, either between positions or between employers, is henceforth a condition -along with possession of educational degrees- for access to vertical mobility, to use Howard BECKER's distinction (1970, pp. 165-176).

To examine how these two types of mobility work together in local public service, the article associates qualitative and quantitative materials. In the first part, it approaches the change favoring spatial mobility over the past 30 years "from above." Analyzing the discourse of politicians and administrative staff in this branch of the civil service as well as that of its analysts, the article shows that the LCS's legal and morphological transformations support their aspirations. The second part nuances these findings through a field study in a small provincial city. The quantitative study of its employees' movements allows identification of gendered, social, and generational structures over the course of their professional careers. Far from the shift toward increasing geographical mobility that has been observed elsewhere, the reality in this municipal administration is that its employees are still quite predominantly locals. Supplemented by the presentation of public employees' actual career paths, this approach "from below" allows the identification of typical forms of mobility that take account of the civil service's heterogeneity.

(4) This text mainly deals with professional promotions over the course of working careers, since we lack the quantitative data needed to estimate the extent of intergenerational social mobility.

\section{Texts and Discourses Favoring Spatial Mobility}

\section{From High Esteem to Critique of "Local" Civil Servants}

A reflection of the crumbling of French local government, the local public service has long been a "splintered continent" (Bellanger, 2004, p. 294). This splintering was palpable in each municipality's administration, due to the diversity of the social milieus represented and the jobs held, but even more so between employees of different municipalities. Indeed, until 1972, an employee could not change jobs from one municipality to another without losing his or her seniority, and there was no truly functional mechanism for advertising vacant positions (there is now a public listing of such jobs). Moreover, by virtue of the status of municipal personnel since 1952,(5) employers could disregard the job descriptions set by the Ministry of the Interior and create their own positions, which made it even more difficult for their holders to change employers. Mocked early on as "Clochemerlism" (taking its name from Chevalier's [1934] satirical novel of village politics), municipal employees' attachment to the territory where they work (often also that of their residence) was still the norm in the first two decades after the Second World War. ${ }^{(6)}$ In the early $1970 \mathrm{~s}$, in preliminary debates on the law to make job transfers possible, (7) the most locally rooted deputies and senators (those simultaneously holding mayoral and parliamentary positions, a common practice in France [KNAPP, 1991]) were still insisting on the "intimacy between town hall and local society" (LoRRAIN, 1991, p. 467) and on the near-paternal connections that unite mayors and their staff. Maujoüan, a republican-independent deputy, spoke of the "human qualities, judgment, and seriousness" that allow the city manager to be the inhabitants" "confidant," while the Socialist senator Mayrou recalled a farmer, city manager before the war, whose professional activity and "devotion" assured his "integration in the milieu."

But these debates also attest to the emergence of a new representation of the local civil service. In fact, since the late 1960s a reform movement took form, driven by politicians with less local careers, academics (especially in law) and State civil

\footnotetext{
(5) Loi du 28 avril 1952.
}

(6) More urban zones, such as the ring around Paris, are exceptions in this regard, since mechanisms for circulating personnel (such as inter-communal civil service hiring campaigns) were established there between the two world wars (BELLANGER, 2001). (7) Above all, the law would initiate a policy of continuing education for local public employees. These debates may be consulted in the Journal Officiel, 1971, Sénat, Débats Parlementaires, 2. Session 1970-1971, janvier-mai 1971, pp. 243-264; Journal Officiel, Assemblée nationale, Débats Parlementaires, 2e session, 1971-1972, 22-35, mai 1972, pp. 1998-2011. 
servants, who gradually challenged the "immobilisme," or resistance to change, of local public employees. The centrist senator Schiélé praised the inter-municipal concours, for example, which "free [the mayor] of the servitude attached to local hiring, give him perspective and independence that are useful for escaping local inertia, which is sometimes quite a problem." More than inadequate geographical mobility, it is the lack of personnel qualifications ${ }^{(8)}$ that holds their attention: more powerful communes need better-trained employees. The Loi du 13 juillet 1972 thus establishes the Center for Communal Personnel Training (Centre de Formation $d u$ Personnel Communal), which organizes its own concours for promotions, adding the applicants' abilities to the hiring and promotion criteria, alongside the older criteria of mayoral recognition.

In the 1970s and 1980s, local administrators, anxious to distinguish themselves from their peers working for the State, continued to defend their knowledge of the "everyday, the real, the concrete" (FONTAINE, 1986, p. 35) and "the population's needs" (LoRRAIN, 1991, p. 468). But several observers of municipal government criticized their "conservative way of functioning, attached to established practices and resistant to new things" (Dion, 1986 , p. 23), which they attributed to the structure of careers marked by their "statutory aspect, their absence of geographic mobility, their slowness" (LoRRAIN, 1977, p. 359). Their reproaches are concentrated on two aspects of personnel management: "social recruiting" and "city hall promotions". Social recruiting designates the sort of public-assistance motivation that lay behind some hires, aiming to help people identified as having social or family difficulties by giving them a (low-paying) job with modest educational requirements. Taking various forms over time (giving hiring priority to war veterans or divorced women, for example) according to the political stripes of local officials, it became the symbol of the mistakes of local hiring and was accused of making the criteria of competence of secondary importance. As for "city hall promotions," though they may have been backed up by skills acquired through continuing education, they are suspected of maintaining local idiosyncrasies to the detriment of efficiency-oriented management tools disseminated since the 1980s (BILAND 2009).

It cannot be said that mayors were quickly won over by the relevance of these changes. The overlap

(8) In $1969,1.5 \%$ of communal employees had an educational level superior to that of the baccalauréat (an educational degree earned by passage of a national examination, capping the conclusion of secondary studies), as compared to $8.3 \%$ of the entire working population (LORRAIN, 1988, p. 88). This differential is partly due to differences between hierarchical structures (with an over-representation of implementing positions in the LCS), but until the 1980s it is also observed among civil servants with similar duties. of the electoral territory and the local employment market is the source of actors' reciprocal interests: elected officials hire their electors and respond to the growing demand for work due to rising unemployment; inhabitants, especially those from the working classes, may work where they live and put their "capital of autochthony" to good use (RETIËRE, 2003). Moreover, such new hires usually have experience as skilled workers in local businesses, which makes them attractive to communes. But since the early 1980s, three factors have made geographical mobility attractive for local elites: closer legal equivalencies with the State civil service, transformations in the local institutional landscape that modify the LCS's morphology, and pressure to bring public budgets under control.

\section{Toward a Local Government Job Market?}

Speaking of the local civil service in terms of a job market can be doubly unsettling. First of all, the term goes against the statutory regulation that is supposed to characterize the French civil service, coming from the career system. ${ }^{(9)}$ But the LCS is nonetheless quite far from this model. In particular, a considerable number of employers ${ }^{(10)}$ choose their employees directly, even those who have passed a concours. The second mark against the market metaphor is that local public employees' low mobility infringes on the criteria of fluidity. This reservation has been partially lifted since the early 1980s. Legal, morphological, and managerial developments in the LCS have encouraged circulation between employers, contributing to the construction of an internal market(11) that is no longer limited to a single local government but now includes all local public institutions. This market remains incomplete: many forms of segmentation - geographical and political in particular- still limit its unification. In sum, if many trends favor mobility between local governments, or even between the SCS and the LCS or the public and private sectors, they remain limited. Their development seems to be the political and managerial future, inscribed in the vast reform movement of public administrations of which the LCS is supposed to be the "laboratory." (12)

Alongside legal developments, the movement bringing local public employees' statuses into conformity and integrating them, by rights, into

(9) In this system, the employee is not hired for a given (potentially temporary) position, but to follow a career path marked by different forms of advancement as well as changes in the kind of work they do. The grade is guaranteed, but the position may change (AuBY et al., 2005, p. 11 onward).

(10) Today there are over 57,000 local public employers for approximately 3 million employees (DGCL, 2011, p. 103).

(11) Usually defined as the institutional unit in which salaries, hiring, and mobility are determined by administrative rather than market procedures (DORINGER, PIORE, 1971).

(12) According to Brice Hortefeux, at the time minister responsible for local governments, to the National Assembly, October 2006. 
the fold of the civil service obviously must also be mentioned. In 1983-84, the creation of the local civil service (fonction publique territoriale), which accorded statutory protections to its employees, seemed to go hand in hand with the prerogatives that decentralization granted to local elected officials (SCHRAMECK, 1995, pp. 14-15; DuRAND, 2004, pp. 222-225). The Loi du 13 juillet 1983 and the Loi du 16 janvier 1984 favor mobility within the civil service: transfers were henceforth possible between all kinds of local governments and local political institutions. It also became possible for local-level employees to work "on loan"(13) in State-level administrations. Moreover, several thousand civil servants working for prefectures and public works services (Directions Départementales de l'Équipement) become civil servants for General and Regional Councils -a movement renewed in 2006-8 in the aftermath of the second step ("Act 2") of decentralization. (14) Beyond the legal framework, the dynamic of local public institutions turns out to be favorable. Between the growth of departmental and regional institutions and the rising strength of inter-communal institutions since the 1990 s, the proportion of municipal-level employment was greatly reduced (representing only $56 \%$ of the total local civil service). Moreover, the 1984 law created many institutions (such as the $\mathrm{CNFPT}^{(15)}$ and departmental management centers, centres départementaux de gestion) making hiring and management practices uniform and offering a common site for local civil servants' socialization that makes it easier for them to project themselves into other jobs, subjectively as well as objectively. Moreover, reinforcing the proportion of higherranking civil servants has given a more prominent role to their professional associations, ${ }^{(16)}$ in which

(13) "Le détachement" and "la mise à disposition" in French, which are legally distinct but functionally similar practices where an employee may go work in another place (branch or level of government, geographical location) while formally still working for the same civil institution that hired her in the first place. Nonetheless, few take advantage of this possibility. On September 30, 1997, 1212 State civil servants were working in local governments, while 1117 local civil servants were working "on loan" to State administrations (AuBY et al., 2005, p. 520).

(14) With the application of the Loi du 13 aout 2004 relative aux libertés et responsabilités locales, 133,000 jobs (in fulltime equivalent) were transferred from the SCS to the TSC over this two year period (DGAFP, 2010, p. 72).

(15) The CNFPT (Centre national de la fonction publique territoriale) organizes continuing education and concours for territorial-level civil servants.

(16) The most influential are the Association des administrateurs territoriaux de France (Association of French Territorial Administrators), the Association des ingénieurs territoriaux de France (Association of French Territorial Engineers), the Syndicat National des Directeurs Généraux des Collectivités Territoriales (National Union of General Directors of Local Governments, representing the leadership of local authorities) and the alumni association of the Institut National des études territoriales (INET; National Institute of Territorial Studies). members build networks that are useful to interemployer mobility.

The legal and managerial changes that have taken effect since the late 1980s have likely reduced elected officials' preference for permanent personnel. Less constrained to recruit civil servants, pressed to limit their staff size in order to control local budgetary expenses, ${ }^{(17)}$ they also have an easier time attracting people who have worked in the private sector. There is a specific concours for them, known as the "third way," and their seniority is now partially taken into account. Of course, local hiring persists, especially in lower positions. It is increasingly rare for it to take the form of social assistance, however: with the exception of subsidized jobs ${ }^{(18)}$ there are clearly fewer hires for less-skilled positions than before ( $\mathrm{LE}$ Lidec, Montricher, 2004). The trend to privatize the civil service, understood as the rapprochement of administrative law and general labor regulations (Code du travail) and more generally as the public sector's adoption of management practices said to come from the private sector (DeLvové, 2006), is ultimately an external factor of mobility. Yet the creation of the public law indefinite-term contract (or CDI, through what is known as the Dutreil Law, Loi du 26 juillet 2005) ${ }^{(19)}$ seems not to fit with this objective. Such public indefinite-term contracts do allow certain contract-holders to obtain a secure job status, but without the possibility for transfer, which is only available for civil servants.

In addition, the structural politicization of local administrative workers is changing under this contemporary norm of geographic mobility. While a city manager's loyalty to a mayor used to be forged over the course of a long-term relationship, it has gradually become contractual and of a limited duration. Public employers may now link city managers' contracts to the mayors' wills and electoral calendars. Reported for the first time following the 1977 municipal elections (marked by a victory for the Left), the local spoils system has become an old chestnut for the specialized media, which does not hesitate to use the soccer metaphor of the "mercato" (trading season) in its coverage (LE SAOUT, 2011, p. 4). If we do observe a strong increase in city managers' mobility since the mid-1990s (ibid, pp. 6-7), we also know that the changes among the top local administrators are not the only factors

(17) Among the ratios defined by the Loi du 6 février 1992 to make local management more rational and transparent, the relationship between personnel expenses and operational costs figure prominently (LE LIDEC, 2006, p. 39).

(18) These private-law contracts for "emplois aidés" concern 57,000 employees in 2009 (DGCL, 2010, p. 1).

(19) The dispositions of this law are confirmed by the proposal for a law relative to the access to tenured employment and the improvement of working conditions of contractual employees in the civil service presented to the Council of Ministers September 7,2011, which nonetheless allows for the possibility of access to civil servant status. 
behind it. Many contemporary senior civil servants have integrated the notion that mobility between local governments is a condition for professional ascension. Barely one high-level employee in ten has passed his or her whole career in the same local government (BACHELET, 2006). Transfers, which are now permitted through these legal changes, are facilitated by the nation-wide announcement of job openings (in the Gazette des communes, Lettre du cadre territorial, Le Moniteur, and Télérama) and by the few personal connections between administrative staff and elected officials in the largest local governments (LE SAOUT, 2011, p. 11).

This geographical mobility distinguishes these administrative workers from other employment categories (KouBI, 2005, p. 77). Transfers represented $25 \%$ of senior administrative (Category [Catégorie] A) hires in 2007, as opposed to $7 \%$ of hires in lower position (Category [Catégorie] C) (Observatoire, 2010, p. 3). Making local hiring channels autonomous makes hiring administrative workers different from hiring implementation workers, for which local authorities often use the services of the national unemployment office, Pôle Emploi. It distinguishes between people from the working classes, whose paths to promotion have historically been built locally, and people coming from the middle classes, who experience spatial mobility early on through their studies and marital alliances. ${ }^{(20)}$ The LCS's structure over-represents implementation positions, accounting for $78 \%$ of LCS employees (DGCL, 2011, p. 105). Combined with the historical preference for "locals," this morphology doubtlessly explains why local government employees remain little geographically mobile compared to those of other sectors. Over the 1990s an average of $2 \%$ of them yearly changed the geographical area where they worked, compared to $4 \%$ of State employees and $13 \%$ in the private sector (Koubi, 2005, p. 69; PAuron, 2003, p. 93). As we will demonstrate shortly, the contemporary norm of mobility weighs unevenly on social groups, according to the economic, symbolic, and relational costs that are associated with it.

\section{Social, Gendered, and Generational Patterns of Career Mobility in a Small Provincial City}

To nuance these general trends and study the specific factors that orient professional careers, the monographic scale proves to be appropriate. Subject to situating the studied local government in terms of characteristic indicators (demographic strata, political stripe, regional labor market, location in the urban structure), it allows a fine-grained study of dynamics that are too often obscured by their agglomeration in national data. By using retrospective logistic regression to analyze the different kinds of mobility the employees of a small provincial city have experienced in the past (between departments, hierarchical categories, and employers) (see Box 1 ), we are then able to examine the generational, gendered, and social structures of their careers (see Table 1).

\section{Box 1 \\ Presentation of the Local Government Studied and the Data Collected}

The fifth-largest commune in its department, Tozay is a historically industrial city. Yet since the early 1970 s, several structural changes led to the decline of its population, from 20,000 inhabitants 40 years ago to 15,000 today. The development of the service sector in the local job market is especially visible in the rising importance of public employment: local government (city hall) and public establishments (the hospital) now top the list of employers. Here as elsewhere (LE LIDEC, MONTRICHER, 2004, p. 22), the position of the downtown, frequented by tourists, also reinforces the number of municipal employees, numbering 376 at the time of the study (2006-7).

The study is based on interviews with elected officials and employees and on consultation of all employees' personnel files, which are kept in the personnel office. The decrees contained therein allow the reconstruction of the employees' careers, while data on civil status and educational degrees provide the socio-demographic indicators. The most long-standing employees of the city were recruited in the early 1970 s, at the moment when the "Union of the Left" ticket came into office, a position it kept until 1995. Led by a Communist mayor, this majority was then beaten by the right before a return victory of the Left in the 2001 election. Put another way, the great majority $(78 \%)$ of these employees were hired while the municipal elected official was identified as "left."

The database built on the basis of these files includes several hiring cohorts. We acknowledge the database is incomplete, since it does not include people who left the city after having worked there. Its representation of geographical mobility is thus partial: it is individuals who have worked for another public employer before being hired at Tozay who are defined as geographically mobile. That is, this study does not cover the mobility of those leaving Tozay for the private sector or other public employers. On the other hand, it does allow us to see the current composition of a city administration of a few hundred employees. These employees' characteristics are presented in Table 1. 
Table 1: Who are Tozay City Employees?

\begin{tabular}{|c|c|}
\hline Employee characteristics & Percentage of total \\
\hline \multicolumn{2}{|l|}{ Place of birth } \\
\hline Tozay & $56 \%$ \\
\hline Same department, excluding Tozay & $16 \%$ \\
\hline Another department & $28 \%$ \\
\hline \multicolumn{2}{|l|}{ Gender } \\
\hline Male & $61 \%$ \\
\hline Female & $39 \%$ \\
\hline \multicolumn{2}{|l|}{ Age } \\
\hline Under 30 & $7 \%$ \\
\hline $30-39$ & $20 \%$ \\
\hline $40-49$ & $40 \%$ \\
\hline 50 and older & $33 \%$ \\
\hline \multicolumn{2}{|l|}{ Educational degree* } \\
\hline None, CEP, BEPC & $24 \%$ \\
\hline $\mathrm{BEP}$ or CAP & $45 \%$ \\
\hline Baccalauréat or higher & $31 \%$ \\
\hline \multicolumn{2}{|l|}{ Civil service concours } \\
\hline Never taken & $47 \%$ \\
\hline Already passed & $53 \%$ \\
\hline \multicolumn{2}{|l|}{ Age at entry into public employment } \\
\hline Under 30 & $58 \%$ \\
\hline $30-39$ & $30 \%$ \\
\hline $40-49$ & $10 \%$ \\
\hline 50 and older & $2 \%$ \\
\hline \multicolumn{2}{|l|}{ Hierarchical category in 2006} \\
\hline Lower $(\mathrm{C})$ & $80 \%$ \\
\hline Mid-ranking (B) & $14 \%$ \\
\hline Upper (A) & $6 \%$ \\
\hline \multicolumn{2}{|l|}{ Work category in 2006} \\
\hline Public works & $59 \%$ \\
\hline Administrative & $21 \%$ \\
\hline Other & $20 \%$ \\
\hline
\end{tabular}

* CEP : now-obsolete diploma marking completion of primary school; BEPC : diploma marking completion of middle school; BEP : a secondary-level diploma marking acquisition of training in a professional field; CAP : a secondary-level diploma received following successful completion of training in a manual trade.

Reading note: $56 \%$ of employees were born in Tozay, as opposed to $16 \%$ born in the same department as Tozay, and $28 \%$ in another department of France.

Field: Civil servants and employees under regular contract with the city of Tozay, 2006-7.

Source: Database assembling data from personnel files in 2006-7 $(\mathrm{n}=376)$

\section{Vertical, Hierarchical, Spatial: the Three Forms of Mobility}

Nearly a third of Tozay city employees (29\%) have already changed divisions, which makes it the most frequent form of mobility for municipal staff. Unsurprisingly, this horizontal mobility ${ }^{(21)}$ is even more likely if one was hired young, as seen in Table 2. But knowing that employees were hired on average a little over 14 years previously, one is inclined to

(21) Not being directly linked to the administrative logic that reigns over the construction of personnel files, job and duty changes are only imperfectly indicated in the files. This is why I chose mobility between divisions, which is better recorded, to estimate horizontal mobility within the local government. relativize this inter-divisional mobility. Despite the time spent working for the city government, opportunities to change position remain relatively infrequent. So who are these internally mobile employees? Although it might seem that passing a concours would mainly be associated with vertical mobility, it also proves to be favorable to horizontal mobility: $67 \%$ of the people who were "mobile" between divisions passed a concours, compared to $27 \%$ of those who have always worked in the same division. And yet, even if it is not always associated with mobility in hierarchical category, changing divisions often means an evolution in job tasks, requiring new skills. Over the course of interviews with the employees, most of these changes were presented as voluntary and associated with an increased interest in work. Changing division also relates to the small social mobility that earned the LCS its reputation as a promotional job market (BILAND, 2010b, pp. 135-136). Neither educational degree nor hierarchical category are significantly associated with prior forms of mobility, a possible sign of the small movements with which they are associated. They are also signs that the employees we meet in Tozay were able to stay because they found horizontal mobility there, or that those who left had more generous promotions. In any case, there are more positions available for people with lower qualifications, and because it is wearing to do the most demanding jobs for decades, mobility between divisions seems more socially egalitarian than the others.

The nature of job duties still makes this mobility more or less probable. Employees in administrative jobs had the highest likelihood of having changed divisions. Their versatility (as seen in the variety of tasks taken on by a manager, for example) would facilitate the transition from one division to another. ${ }^{(22)}$ The high proportion of women in administrative positions ( $70 \%$ in Tozay) should not lead us to think, however, that women have greater access to this mobility between job-types. Table 2 suggests the contrary, since the women working in 2006 were less likely to have experienced a change in division over their careers than their male colleagues. This statistical observation agrees with accounts gathered in interviews. In several couples composed of commune employees, the man's professional success is based on his wife's support, whose engagement in her work is subordinated to her family responsibilities (see Box 2).

(22) To back up this argument, we wish to point out that only 16 employees (4\% of the staff) have changed work category since being hired by Tozay. It is usually someone leaving the social services category ( 9 cases), or the public works category for the administrative ( 5 cases). Two of these work category changes represent significant job changes (from school janitor to the finances division, for example), but these are cases of regularization of job status due to the creation of a new job category (teachers' aids) or a small movement between jobtypes in the same work environment (from school janitor to teachers' aid). 
Table 2: Which Employees Have Changed Divisions Since Being Hired by City Hall?

\begin{tabular}{|c|c|c|}
\hline Employee characteristics & $\begin{array}{l}\text { Percentage } \\
\text { "mobile" }\end{array}$ & $\begin{array}{l}\text { Odds } \\
\text { ratio }\end{array}$ \\
\hline \multicolumn{3}{|l|}{ Place of birth } \\
\hline (Tozay) & $37 \%$ & \\
\hline Same department, excluding Tozay & $17 \%$ & 0.35 \\
\hline Another department & $15 \%$ & \\
\hline \multicolumn{3}{|l|}{ Gender } \\
\hline (Male) & $39 \%$ & \\
\hline Female & $28 \%$ & 0.4 \\
\hline \multicolumn{3}{|l|}{ Age } \\
\hline Under 30 & $4 \%$ & \\
\hline $30-39$ & $27 \%$ & \\
\hline $40-49$ & $28 \%$ & \\
\hline 50 and older & $34 \%$ & \\
\hline \multicolumn{3}{|l|}{ Educational degree } \\
\hline (None, CEP, BEPC) & $33 \%$ & \\
\hline $\mathrm{BEP}$ or CAP & $40 \%$ & \\
\hline Baccalauréat or higher & $29 \%$ & \\
\hline \multicolumn{3}{|l|}{ Other public employer } \\
\hline (None) & $30 \%$ & \\
\hline Before working for Tozay & $12 \%$ & 0.41 \\
\hline \multicolumn{3}{|l|}{ Civil service concours } \\
\hline (Never taken) & $27 \%$ & \\
\hline Already passed & $41 \%$ & 2.0 \\
\hline \multicolumn{3}{|l|}{ Age at entry into public employment } \\
\hline Under 30 & $35 \%$ & \\
\hline $30-39$ & $31 \%$ & $0.97 *$ \\
\hline $40-49$ & $32 \%$ & \\
\hline 50 and older & $20 \%$ & \\
\hline \multicolumn{3}{|l|}{ Hierarchical category in 2006} \\
\hline Lower $(\mathrm{C})$ & $31 \%$ & \\
\hline Mid-ranking (B) & $17 \%$ & \\
\hline Upper (A) & $20 \%$ & \\
\hline \multicolumn{3}{|l|}{ Work category in 2006} \\
\hline (Public Works) & $29 \%$ & \\
\hline Administrative & $32 \%$ & 2.4 \\
\hline Other & $18 \%$ & \\
\hline Total & $29 \%$ & \\
\hline
\end{tabular}

* For this table as for the others, the odds ratio for age in 2006 and age at entry into public employment are calculated based on continuous variables. In this case, the effect of age at entry into public employment on mobility between divisions is read in the following way: the later one enters into public employment, the less likely one is to experience mobility between Tozay city divisions.

Reading note: $39 \%$ of men changed divisions over the course of their careers as Tozay city employees, as opposed to $28 \%$ of women, who, all other things being equal, thus have a relative likelihood 0.41 times lower than their male colleagues to have experienced such a mobility.

Field: Tenured employees, interns, and employees under regular contract with the city of Tozay, 2006-7.

Source: Database assembling data from personnel files in 2006-7 $(\mathrm{n}=376)$.

\section{Box 2}

\section{Two "Paired" Trajectories in Administrative Work}

The respective careers of Gilles and Maryse Moine illustrate these gendered inequalities in administrative jobs. Son of a shoe repairman having obtained a baccalauréat, Gilles starts working at city hall in 1972, after having worked a year for the préfecture. His first grade is that of clerk (commis, Category C), before passing two successive concours to reach the grade of chief clerk (rédacteur, Category B) in 1975, then manager (attaché, Category A) in 1979. He goes on to direct several divisions before his retirement in 2004, reaching the grade of senior manager (attaché principal) via internal promotion. Maryse joins him at city hall in 1977, after having worked in a supermarket and bearing their first child. Granted, she is less educated than Gilles (she has a BEPC). Hired as a telephone operator (the bottom of Category C), she does not take any concours, and works part time for a long time. She goes on to work in the civil status and election division. Promoted by seniority to "administrative assistant" (the new name for clerks) in 1990, she never manages to reach the level of chief clerk.

The personnel files also indicate the existence of a negative correlation between internal mobility and spatial mobility. One is even more likely to have experienced a change in divisions when one was born there: local roots indeed seem to work in favor of those who remain in Tozay, more often beneficiaries of a "city hall promotion." Likewise, having worked for another public employer is negatively associated with division changes, indicating a form of exclusivity between internal and external careers.

Moving on to examining the factors correlated with a past change of hierarchical category (from $C$ to $\mathrm{B}, \mathrm{B}$ to $\mathrm{A}$, or even $\mathrm{C}$ to $\mathrm{A}$ ), we look at a specifically vertical form of mobility that is much less frequent ( $7 \%$ of employees). As seen in Table 3, there is, all other things being equal, an over-representation of people holding a baccalauréat degree among those who have "climbed the ranks." This observation testifies to the role of degrees in the internal selection of employees, for example for promotions coming to compensate for a downgrade early in their career. (23) Even in an environment reputed for its promotions, academic prerequisites

(23) Surprisingly, the non-signification of the "concours" factor may be explained by this salience of educational degrees: if one holds a degree, passing a concours does not significantly increase one's chances of changing hierarchical category, even if the overall effect of such concours is obviously positive: 21 of the 27 people having changed hierarchical category over their career $-78 \%$ - had passed a concours. By contrast, only $49 \%$ of people not having changed hierarchical category have passed one. 
are significant. (24) We thus note that the five employees having begun their career in Category $\mathrm{C}$ who reached Category A by the time of the study all hold the baccalauréat: four even hold higher education degrees, although they are rather older than the average (four of the five are in their fifties).

Table 3: Who Are the Employees Who Changed Hierarchical Category Mid-Career?

\begin{tabular}{|c|c|c|}
\hline Employee characteristics & $\begin{array}{l}\text { Percentage } \\
\text { "mobile" }\end{array}$ & $\begin{array}{l}\text { Odds } \\
\text { ratio }\end{array}$ \\
\hline \multicolumn{3}{|l|}{ Place of birth } \\
\hline (Tozay) & $5 \%$ & \\
\hline Same department, excluding Tozay & $5 \%$ & \\
\hline Another department & $22 \%$ & 2.5 \\
\hline \multicolumn{3}{|l|}{ Gender } \\
\hline (Male) & $8 \%$ & \\
\hline Female & $6 \%$ & \\
\hline \multicolumn{3}{|l|}{ Age } \\
\hline Under 30 & $0 \%$ & \\
\hline $30-39$ & $3 \%$ & 4.2 \\
\hline $40-49$ & $7 \%$ & \\
\hline 50 and older & $13 \%$ & \\
\hline \multicolumn{3}{|l|}{ Educational degree } \\
\hline (None, CEP, BEPC) & $5 \%$ & \\
\hline $\mathrm{BEP}$ or CAP & $2 \%$ & \\
\hline Baccalauréat or higher & $17 \%$ & 4.3 \\
\hline \multicolumn{3}{|l|}{ Other Public employer } \\
\hline (None) & $5 \%$ & \\
\hline Before working for Tozay & $28 \%$ & \\
\hline \multicolumn{3}{|l|}{ Civil service concours } \\
\hline (Never taken) & $4 \%$ & \\
\hline Already passed & $11 \%$ & \\
\hline \multicolumn{3}{|c|}{ Age at entry into public employment } \\
\hline Under 30 & $9 \%$ & \\
\hline $30-39$ & $5 \%$ & 0.89 \\
\hline $40-49$ & $0 \%$ & \\
\hline 50 and older & $17 \%$ & \\
\hline \multicolumn{3}{|l|}{ Work category in 2006} \\
\hline (Public works) & $5 \%$ & \\
\hline Administrative & $14 \%$ & 4.0 \\
\hline Other & $8 \%$ & \\
\hline Total & $7 \%$ & \\
\hline
\end{tabular}

Reading note: $5 \%$ of public works employees, compared to $14 \%$ of administrative staff, have changed hierarchical category. All other things being equal, administrative employees are thus 4.0 times more likely to have known such mobility than their colleagues in public works.

Field: Civil servants and employees under regular contract with the city of Tozay, in 2006-7.

Source: Database assembling data from personnel files in 2006-7 $(\mathrm{n}=376)$.

The two age-related variables seem more heuristic. The oldest employees, who entered local government at the youngest age, have more chance of having experiences professional ascension. In fact, large movements take time, as illustrated by the steps taken by Gilles Moine to go from the

(24) We know that in general, holders of general degrees are more numerous to go from worker or laborer positions to midlevel and managerial positions (CHAPOULIE, 2000, pp. 42-43). bottom to the top of the ladder. If one must have spent some time in the city offices, it might also be because current career management conditions allow less vertical mobility within the same city government than they used to. The comparison of the careers of employees in their forties and fifties is striking in this regard. The youngest are half as likely as their elders to have changed hierarchical category ( $7 \%$ compared to $13 \%$ ). Will they have the same success in coming years? It is far from certain, because hierarchical changes usually take place around the age of 40 . In fact, the different destinies of these two cohorts, only a few years apart, seem to correspond to an abrupt transition that took place in the mid-1990s: in municipalities the size of Tozay, the transfer of concours and promotions to departmental management centers heightens the selectivity of these two mechanisms (BILAND, 2009, p. 25). In addition, the recent but rapid process of bringing educational requirements for LCS and SCS employment into conformity (25) contributes to raising the academic prerequisites for professional ascension.

Local roots are also a meaningful factor for this type of mobility, but in a way that runs opposite to the inter-divisional mobility presented above. It is thus people born outside the department where Tozay is located who, all other things being equal, have a greater likelihood of having changed hierarchical category.

What to make of the distinctiveness of the administrative work category? Do "administrators" accumulate vertical and horizontal moves? The careers of individuals marked with high rates of promotion (such as Gilles Moine) seem to indicate this is the case: their division changes generally follow closely behind success in a concours and accession to a higher hierarchical status. In other terms, large moves (in terms of job-type and hierarchical displacement) are characteristic of the administrative category, but they remain rare. In contrast, employees in public works positions have access, in great number, to more modest hierarchical shifts (changing grade within a given category).

At the end of the study of these two forms of mobility, we ultimately observe a polarization opposing more highly educated ${ }^{(26)}$ employees coming from elsewhere, who have most often experienced hierarchical mobility and work in the administrative staff, on one side, and on the other, employees originating from Tozay, more often in the public works staff,

(25) This is especially palpable in the profiles of candidates having passed the concours, who are regularly over-educated in terms of the official requirements.

(26) $56 \%$ of employees born outside the department have a baccalauréat degree, as compared to $20 \%$ of employees born in Tozay and $27 \%$ of those born in the same department. 
whose mobility is internal.(27) We will refine this analysis by examining the determinants for mobility between local governmental employers.

The articulation between geographic position and social position is enriched with the analysis of mobility between public employers (see Table 4). Tozay employees are no exception to the model for entering into public employment summarized in the beginning of the article: $60 \%$ of informants had worked in the private sector $(10 \%$ in permanent positions, $50 \%$ on limited-term contracts or as temporary workers) before becoming a civil servant. The average age of entry into city government was nearly 30 . Do these private-public shifts couple with mobility between local governments? To return to the internal local civil service job market hypothesis, one last analysis compares individuals who have worked for another public employer prior to Tozay with those for whom Tozay city hall is their first public employer. The magnitude of this last type of mobility is limited: $12 \%$ of employees have already worked for at least one other local government, and $2 \%$ for the State. It is true that the assembled data only gives access to some employment changes: they do not allow us to follow Tozay employees who have left to work elsewhere. Nonetheless, only $6 \%$ of the people hired prior to 1995 have previously worked for another public employer. Until the 1990s, moves between public and private employment, most often within the same local scene, are more frequent than moves between public employers, synonymous with spatial mobility. Human resources records count 25 resignations between 1986 and 1993, compared to only four transfers over the same period. Things have clearly changed since: $18 \%$ of employees hired since 1995 had already had experience in the public sector, and this is the case for $27 \%$ of those who arrived since 2001 . On the nationwide scale, over the $1990 \mathrm{~s}, 2-3 \%$ of employees changed from one local government to another in a given year (KouBI, 2005 , p. 73). Unsurprisingly, the larger the administration, the less frequent transfers take place: with nearly 400 employees, Tozay's administration has already reached a size large enough to offer career prospects internally. In this regard, the administrative staff, for whom jobs are less numerous and less specific than for the public works staff, is an exception: it is particularly favorable to mobility between local governments (see Table 4).

(27) The insignificance of the "gender" variable in hierarchical mobility leads one to think that there are no differences between men and women in accessing hierarchical mobility. This hypothesis goes against observations of male over-representation in supervisory positions, including those who had been promoted (four of the five employees who moved from Category $\mathrm{C}$ to $\mathrm{A}$ are men, for example). Other associated factors such as work category (which would be different for men and women) could explain this insignificance.
Table 4: Who Are the Employees Having Worked for Another Public-Sector Employer?

\begin{tabular}{|c|c|c|}
\hline Employee characteristics & $\begin{array}{l}\text { Percentage } \\
\text { "mobile" }\end{array}$ & $\begin{array}{l}\text { Odds } \\
\text { ratio }\end{array}$ \\
\hline \multicolumn{3}{|l|}{ Place of birth } \\
\hline (Tozay) & $4 \%$ & \\
\hline Same department, excluding Tozay & $14 \%$ & 4.5 \\
\hline Another department & $35 \%$ & 4.2 \\
\hline \multicolumn{3}{|l|}{ Gender } \\
\hline (Male) & $11 \%$ & \\
\hline Female & $14 \%$ & \\
\hline \multicolumn{3}{|l|}{ Age } \\
\hline Under 30 & $11 \%$ & \\
\hline $30-39$ & $9 \%$ & \\
\hline $40-49$ & $15 \%$ & 4.2 \\
\hline 50 and older & $10 \%$ & \\
\hline \multicolumn{3}{|l|}{ Educational degree } \\
\hline (None, CEP, BEPC) & $7 \%$ & \\
\hline $\mathrm{BEP}$ or CAP & $3 \%$ & \\
\hline Baccalauréat or higher & $30 \%$ & 4.3 \\
\hline \multicolumn{3}{|l|}{ Civil service concours } \\
\hline (Never taken) & $8 \%$ & \\
\hline Already passed & $19 \%$ & 2.6 \\
\hline \multicolumn{3}{|l|}{ Age at entry into public employment } \\
\hline Under 30 & $14 \%$ & \\
\hline $30-39$ & $9 \%$ & \\
\hline $40-49$ & $11 \%$ & 0.89 \\
\hline 50 and older & $17 \%$ & \\
\hline \multicolumn{3}{|l|}{ Hierarchical category in 2006} \\
\hline Lower $(\mathrm{C})$ & $5 \%$ & \\
\hline Mid-ranking (B) & $30 \%$ & \\
\hline Upper (A) & $52 \%$ & \\
\hline \multicolumn{3}{|l|}{ Work category in 2006} \\
\hline (Public works) & $5 \%$ & \\
\hline Administrative & $19 \%$ & 2.9 \\
\hline Other & $23 \%$ & \\
\hline Total & $12 \%$ & \\
\hline
\end{tabular}

Reading note: $5 \%$ of public works employees have already worked for another public employer, compared to $19 \%$ of the administrative staff, who thus have, all other things being equal, 2.9 times less of a chance of having experienced such a mobility as their colleagues in the public works.

Field: Civil servants and employees under regular contract with the city of Tozay, in 2006-7.

Source: Database assembling data from personnel files in 2006-7 ( $\mathrm{n}=376$ ).

This form of mobility tends to increase but is unequally frequent according to work category, and is above all over-determined by the employee's birthplace. Tozay natives have very little chance of having worked for another public employer. Inversely, being born elsewhere and having passed a concours are two of the most frequently shared characteristics ${ }^{(28)}$ among those who have worked for another public employer. Interviews with concours candidates show that they strongly anticipate changing government employers, a possible result of their

(28) An analysis (not published here) indicates that the probability of having passed a concours is higher among employees born outside of Tozay. 
success (BILAND, 2010a, p. 61). Some even admit being discouraged, having gradually come to realize that it will not be possible for them to "advance" where they are. If the development of concours, henceforth organized external to local governments, appears to be a key factor in the rising importance of transfers, it can also be held responsible for the increasing rarity of ascendant trajectories in the working classes strongly attached to local sociability (SCHWARTZ, 1998, p. 80).

The insignificance of educational degree and hierarchical category seems explicable by the salience of the "birthplace" effect: because only $22 \%$ of Category A employees were born in Tozay (as opposed to $66 \%$ of the C's), and because only $36 \%$ of employees with a Baccalauréat were born in Tozay (compared to $66 \%$ of those with CAP or BEP degrees), one may consider that birthplace imposes itself on these two characteristics that are largely correlated with it.

To conclude, what to make of the insignificance of age and seniority variables? We know that the propensity to geographical mobility is largely a question of life cycle: in the LCS, as in the SCS and private sector, it is especially intense before age 30 , over the period when one is entering the job market (DupaYs, 2003, p. 41; Pauron, 2003, p. 105; KouBI, 2005). In this age bracket, transfers have become routine, because they are necessary for a successful career. They also correspond to the personal aspirations of many young working people, who are still in a transitional phase between their family of origin and their family of procreation and have already experienced mobility, starting with higher education. Many make mobility a condition for a sustained interest in work. The injunction to mobility, weighing mostly on people at the beginning and middle of their working lives, tends to reduce the influence of seniority. The younger are more mobile, but the older have had more time to change employers -these two counter-effects might render these variables' effects insignificant. Moreover, among the cohorts hired the farthest back in time, a certain number of employees has left to work elsewhere. And yet use of the personnel files remains limited to a single local government -files are transferred along with the employees. Lastly, if the oldest employees are the least mobile, it is also because the most mobile of their generation no longer work in Tozay. As for the insignificance of the "gender" variable, it seems to relate back to the different motives bringing men and women to change workplaces. In the cover letters (kept in the files) and in interviews, several women indicated they hoped to find work closer to their spouses, while men seem to pursue more autonomous professional plans.

\section{From Workers to Managers: Four Typical Trajectories}

If the regressions are inadequate for accounting for all the motives involved in mobility, they convincingly show the weight of generational membership, social position, and gender on professional careers in local government. At the end of this analysis, one can identify four modal trajectories at the Tozay city hall, which articulate gender, generation, hierarchical position, and professional specialization.

The first is typical of men, skilled workers, holders of BEP or CAP degrees, Tozay natives, and those who have locally experienced small movement in status within the same work unit (see Box 3).

\section{Box 3 \\ Technical Employment and Internal Mobility}

The current head of the CGT labor union, born in 1951, experienced this ascension within Category C. He has a BEP degree, and worked ten years or so as a skilled worker in a printing business before being laid off and starting at city hall in 1982. Though he began at the lowest grade (professional worker's assistant), a few years later he passed the internal concours, organized locally, to become a painter (with the status of technical agent). He was then promoted by seniority to skilled technical agent, then chief technical agent. In 2000, he was re-classed as a clerk (in the same division) due to health problems.

Since the mid-1990s, however, these ascendant careers are less likely to happen, while simultaneously the academic requirements for the initial hire rise (often requiring a professional baccalauréat, or even a BTS, a technical diploma indicating two years of study beyond the baccalauréat).

Demonstrating the gendered division of labor, the second trajectory is the feminine equivalent of the first. It is associated with administrative jobs and mid-level general educational degrees (BEPC and baccalauréat), marked by a certain degree of mobility between divisions (in similar jobs) and by more limited job status progression (see Box 4).

\section{Box 4}

\section{Administrative Work and Limited Advancement}

The career of the current secretary of Support Services is a good example. In 1982, upon leaving secretarial school, she passed the clerk's concours and was soon hired by the town hall of the Parisian suburban town where she was born. She worked there as a chief clerk for six years, then became secretary of the director of Support Services, a position she held for two years before getting a transfer to Tozay. Motivated by the earlier transfer of her husband, this change of region put her in a similar job, which she will keep indefinitely. 
The third trajectory distinguishes between the managers (Category A) from the two implementing categories just mentioned. In contrast, "Category As" frequently have concours experience from the very beginning of their careers, from their first efforts to get civil servant status. Apart from this common experience, their careers are strongly differentiated by gender, age, and relationship to the local area. The internal promotion model (which is more masculine and associated with the oldest employees) has been replaced since the mid-1990s with the recruitment of administrators by transfer. In 2006, 15 of Tozay's 21 current Category A administrators (71\%) had been hired during the decade prior to the study. This means this group experienced significant transformations: younger, more often female, these managers also have less personalized relationships with the elected officials (see Box 5).

\section{Box 5}

\section{Promotion and Geographical Mobility of a High-Ranking Civil Servant}

As the trajectory of the current head of the Computing division illustrates, employees hired over the past decade have often experienced several forms of mobility. After a baccalauréat in science and a DUT (post-baccalauréat 2-year technical degree) in computing, he worked briefly in two computing businesses in the departmental seat, where he passed a city hall-organized concours for a programmer position in 1984. He worked there until 1997, climbing the ranks: chief technician by professional exam in 1993 (which brought him to change divisions), subdivision engineer by concours in 1995 . In 1997 he replied to the city of Tozay's ad in the regional paper, and became head of its Computing division. His spatial mobility (partial, since he still lives in the departmental seat) also corresponds to a professional advancement (he takes the leadership of a division) and to a hierarchical promotion (becoming chief engineer).

This renewal of supervisory positions should be put in relation to Tozay's demographic scale. In fact, it is in communes with a population from 10,000 to 40,000 that the rate of rotation of city managers has been the highest over the past 15 years (Le SAout, 2011, p. 8). Tozay's case suggests that the same might also hold for less high-ranking administrators. Indeed, in city governments of this size, the positions the city hall administration has to offer, which may be satisfactory for employees charged with implementation (see below), may no longer be enough for high-ranking civil servants. We were told of several cases of Tozay administrators who left for other local governments because they were faced with a limited number of accessible jobs in Tozay. Disagreements over urban planning projects drove many of these transfers in the early 1990s, showing the degree to which jobs in local government administration may be politicized (DION,
1986). In 2001 the city hired its first city manager through geographical mobility, as opposed to internal promotion. His ascendant career in several cities similar to Tozay before being hired there illustrates the maintenance of political (or rather, mayoral) control over supervisory job hiring. But the manager is no longer integrated in the local network of associations, unions, and political parties, instead being in the polarized (left/right) national space where territorial administrators circulate. Political preoccupations here join pragmatic goals. Changing employers is often synonymous with a higher salary, and mobility toward the private sector (to which this study does not give access) is the best paying (KouBI, 2005, p. 80).

Although divided between public works and administrative staffs (respectively accounting for $60 \%$ and $20 \%$ of Tozay's total employees), local public employment is not limited to them, either. Employees in the fields of arts, youth services, and sports $\left(18 \%\right.$ of city employees $\left.{ }^{(29)}\right)$ are quite unlike administrators and public works staff. The late institutionalization of these fields into the LCS explains why these employees have more often been contractual, sometimes for many years. ${ }^{(30)}$ In parallel, the nature of their activities (frequently part-time, sometimes seasonal) and their relationship to their line of work (part professional, part vocational) often keeps them at a distance (both objective and subjective) from the status of civil servant (see Box 6).

\section{Box 6 \\ A Job in the Arts: Late Access to Civil-Servant Status}

The city's saxophone teacher represents this profile well. Born in Tozay (where he still lives) in 1969 , he begins to teach for the city at 21 , after having studied at the music school in the departmental seat. A little over a year later, he reaches full-time (20 hours of teaching a week instead of 9 ), but remains a contractual employee. He would have a total of 10 contracts between 1990 and 2002. In 1994 the mayor wrote asking him to take the concours to obtain a permanent status and "invest [himself] more long-term in [his] city." In 1996 he fails the special concours that had been put in place under a national plan for the reduction of employment insecurity. He would have to wait until 2002 to become arts teaching assistant (Category B), under the auspices of another program for transitioning employment-insecure workers into stable jobs, which exempted him from taking a concours.

(29) This rate, which is rather high, is explained by the city's touristic character and the heavy investment in these sectors by the mayor in charge between 1971 and 2005. On the other hand, there is no municipal police, and the medical and social services staffs are limited (they work mostly for the departmental General Councils).

(30) In Tozay, seven of the nine "permanent contract workers" are music or art teachers. 
Councils in the highest position, a hierarchy of employers takes shape according to the benefits and career prospects they offer. The highest aspirations to mobility among implementation employees are also found in the Parisian area. In this suburban context, housing and living conditions accentuate civil servants' long-term aspirations to mobility related to their plans to return to the region they came from. The desire to leave the most working class communes thus motivates some plans to transfer. Taking a distance -both professional and residential- from large urban centers then contributes to distancing oneself from insecure populations. While the theme of bringing administrations closer to the populations they serve inspired many reforms, the weakening of connections of familiarity between inhabitants and civil servants -for social reasons at least as much as geographical (SівLOT, 2006)- contributes to the transformation of relations of service, in the sense of a growing formalization or even managerialization. In contrast, this study of the small city of Tozay showed that despite contemporary injunctions to geographical mobility, an important share of local civil servants remain strongly rooted in the government for which they work and often where they live. That mobility has become commonplace among managers thus contrasts with its limited applicability to Category $\mathrm{C}$ employees. With supervisors coming from elsewhere and the majority of implementation employees having little prospect for mobility, tensions were palpable over the course of our research in Tozay (BILAND, 2010b, pp. 137-138). The former seem to have appropriated the idea that they have to "transfer to succeed" and anticipate the risk of political rejection, while a change in employer, unlikely though it might be, seems costly to the latter. The relative substitutability of their professional skills, as well as the difficulty of reconstructing their family arrangements elsewhere, makes "Category Cs" doubt their employability outside the area where their modest social capital has currency.

This research protocol has proven to be fruitful for considering the structuring traits of careers as well as the meanings civil servants attribute to mobilities, as well as comprehending their interacting effects on employees' work and local public action. Going back and forth between employees and their personnel files allowed individual experiences to be integrated into their spaces of social possibility (reconstructed here in the form of typical trajectories). It illuminated the impulses behind mobilities objectified by the quantitative exploitation of administrative data. These different approaches to mobilities do not always converge. Thus, the "all other things being equal" comparison of men's and women's mobilities leads to limited variations, which expands when one takes account of the gendered structure of professional careers (SiLvera, 1996) or the different relationship each 
gender may have with careers (TeSTENOIRE, 2001). In sum, by studying local and social appropriations of the injunction to mobility (those of public employers and civil servants, respectively), this article confirms the heuristic contribution of comparative views of professional mobilities.

\section{Bibliography}

Arnaud L., Le Bart C., Pasquier R. (dir.) (2006), Idéologies et action publique territoriale. La politique change-t-elle encore les politiques?, Presses Universitaires de Rennes.

Auby J.-M., Auby J.-B., Didier J.-P. (2005), Droit de la fonction publique, Dalloz.

BACHELET F. (2006), «Sociologie, formation et carrière des hauts fonctionnaires territoriaux», Annuaire des Collectivités locales, CNRS éditions, pp. 99-103.

Becker H. (1970), Sociological work. Method and Substance, Aldine.

Bellanger E. (2004), Administrer «la banlieue municipale». Activité municipale, intercommunalité, pouvoir mayoral, personnel communal et tutelle préfectorale en Seine banlieue des années 1880 aux années 1950, thèse d'histoire, Université Paris 8.

Bellanger E. (2001), «L'école nationale d'administration municipale. Des "sans-grade" devenus secrétaires généraux », Politix, n 53, pp. 145-171.

Bellanger E. (2008), «Le personnel communal ou l'empreinte du territoire: construction d'un groupe, politisation et sociabilité municipale», in Bellanger E., Girault J. (dir.), Villes de banlieue. Personnel communal, élus locaux et politiques urbaines en banlieue parisienne au 20e siècle, Créaphis, pp. 151-189.

BiLAND É. (2009), «"Moderniser les ressources humaines” dans une petite ville française: appropriations et contournements des normes juridiques et gestionnaires », Pyramides, $\mathrm{n}^{\circ} 17$, pp. 15-34.

BILAND É. (2010a), «Carrières concourantes. Éléments sur la socialisation par les concours administratifs territoriaux », Terrains et Travaux, $\mathrm{n}^{\circ}$ 17, pp. 57-73.

Biland É. (2010b), «Les usages du statut par les employeurs publics locaux: embaucher et gérer les carrières à la ville des années 1970 aux années 2000», in Cartier M., Retière J.-N., Siblot Y. (dir.), Les salariés à statut. Genèses et cultures, Presses Universitaires de Rennes, pp. 127-139.

Blum A., De la Gorce G., Thélot C. (1985), «Mobilité sociale et migration géographique», Population, vol. 40, $\mathrm{n}^{\circ} 3$, pp. 397-434.

Boltanski L., Chiapello È. (1999), Le nouvel esprit du capitalisme, Gallimard.

Bozon M., Héran F. (2006), La formation du couple. Textes essentiels pour la sociologie de la famille, La Découverte.
Burlen K., Thoenig J.-C. (1998), «Les secrétaires généraux des villes », Politiques et management public, vol. $16, \mathrm{n}^{\circ} 1$, pp. 141-172.

Castel R. (2003), L'insécurité sociale. Qu'est-ce qu'être protégé?, Seuil.

Chapoulie S. (2000), «Une nouvelle carte de la mobilité professionnelle», Économie et statistique, $\mathrm{n}^{\circ} 331$, pp. 25-45.

Chevallier G. (1934), Clochemerle, Le livre de poche, réédition 2004.

Delvové P. (2006), «La privatisation du service de l'État», Pouvoirs, n 117, pp. 107-120.

DGAFP (2010), Rapport annuel sur l'état de la fonction publique 2009-2010, La Documentation française.

DGAFP (2011), Rapport annuel sur l'état de la fonction publique 2010-2011, La Documentation française.

DGCL (2011), Les collectivités locales en chiffres 2011, ministère de l'Intérieur.

Dion S. (1986), La politisation des mairies, Economica.

Doeringer P., Piore M. (1971), Internal Labor Markets and Manpower Analysis, Heath Lexington Books.

DupAYs S. (2003), «La mobilité dans la fonction publique : mythe ou réalité? », in Observatoire de l'emploi public, Rapport annuel 2003, annexe 3, La Documentation française, pp. 39-45.

DURAND D. (2004), Une histoire de la fonction publique territoriale, La Dispute.

Fontaine J. (1986), «Être cadre de catégorie A dans la mairie d'une grande ville», Politiques et management public, vol. 4, $\mathrm{n}^{\circ} 3$, pp. 23-62.

Gollac S. (2005), «La Fonction Publique : une voie de promotion sociale pour les enfants des classes populaires? Une exploitation de l'enquête emploi $2001 »$, Sociétés Contemporaines, $\mathrm{n}^{\circ} 58$, pp. 41-63.

GuÉRARD S. (dir.) (2008), La GRH publique en questions : une perspective internationale, L'Harmattan.

Koubi M. (2005), «La mobilité professionnelle dans les collectivités territoriales. Une première évaluation », in Observatoire de l'emploi public, Rapport annuel 20042005, Annexes, pp. 61-81.

LE BART C. (2011), «Le marketing territorial», in Cole A., Guigner S., Pasquier R. (dir.), Dictionnaire des politiques territoriales, Paris, Presses de Sciences Po. 
LE LIDEC P. (2006), «Choix des modes de gestion des services publics et politiques de recrutement des communes. Quelle place pour la variable partisane?», in Arnaud L., Le Bart C., Pasquier R. (dir.), Idéologies et action publique territoriale. La politique change-t-elle encore les politiques?, Presses Universitaires de Rennes, pp. 35-49.

Le Lidec P., Montricher N. (2004), Décentraliser et gérer. Analyse rétrospective et prospective de l'emploi public dans les collectivités territoriales, La Documentation française.

Le Saout R. (2011), «La mobilité des directeurs généraux des services municipaux comme indicateur d'un rapport renouvelé au travail politique », $11^{\mathrm{e}}$ congrès de l'Association Française de Science Politique, ST 40.

LORRAIN D. (1977), «La situation du personnel communal en France», in IFSA, L'administration des grandes villes, cahiers $n^{\circ} 14$, Paris, Cujas.

LORRAIN D. (1991), «De l'administration républicaine au gouvernement urbain», Sociologie du travail, $\mathrm{n}^{\circ} 4$, pp. 461-484.

OBSERVATOIRE DE L'EMPLOI, DES MÉTIERS ET DES COMPÉTENCES (2010), «Les mouvements de personnels territoriaux en 2007 », Synthèse, CNFPT, n 29.
Pauron A. (2003), «La mobilité des agents titulaires de l'État», Économie et statistique, n 369-370, pp. 93-111.

Raynaud P. (2003), «L'emploi public est tiré par la fonction publique territoriale», Économie et statistique, $n^{\circ} 369-370$, pp. 75-92.

RetiÈRe J.-N. (2003), «Autour de l'autochtonie. Réflexion sur la notion de capital social populaire», Politix, $\mathrm{n}^{\circ}$ 63, pp. 121-143.

Schrameck O. (1995), La fonction publique territoriale, Paris, Dalloz, coll. «Connaissance du droit. Droit public».

Schwartz O. (1998), La notion de "classes populaires》, mémoire pour l'habilitation à diriger des recherches en sociologie, université de Versailles-Saint-Quentin.

Siblot Y. (2006), Faire valoir ses droits au quotidien. Les services publics dans les quartiers populaires, Presses de Sciences Po.

SilverA R. (1996), «Les discriminations salariales entre hommes et femmes, toutes choses inégales par ailleurs», Économies et sociétés, vol. 30, n 11-12, pp. 199-216.

Testenoire A. (2001), «Les carrières féminines: contingence ou projet?», Travail, genre et sociétés, $n^{\circ} 5$, pp. 117-134. 